\title{
GEORGE BAKER: TRANSLATOR OF APARICIO DE ZUBIA'S PAMPHLET ON THE "OLEUM MAGISTRALE"
}

by

\author{
GUSTAV UNGERER*
}

The present article is concerned with identifying the Morisco healer Aparicio de Zubia as the author of a pamphlet on the "Oleum Magistrale" which, in 1566, was published at the instance of the Spanish government after Zubia's death and which, in 1574, was translated by the Elizabethan surgeon George Baker from what seems to have been a French intermediary version. I shall not presume to enter into a discussion about the oil's medicinal virtues, leaving it to scholars interested in the history of chemical medicine to pursue the subject. But besides identifying Zubia as a medical practitioner advocating chemical therapy in a pamphlet published under Baker's name in England, I shall venture to throw some light on Baker as a surgeon who embraced alternative medicine without abandoning traditional science. ${ }^{1}$

${ }^{*}$ Dr Gustav Ungerer, Englisches Seminar, Universität Bern, CH-3012 Bern, Gesellschaftsstrasse 6, Switzerland.

${ }^{1}$ I think it fit to seize the opportunity of providing some biographical information on Baker with a view to complementing and correcting the fragmentary entry in the DNB. I am indebted to the Worshipful Company of Barbers for having supplied me with a typewritten single-leaf account of Baker's career.

George Baker was born in 1540, the second son of Christopher Baker of Tenterden, Kent. His grandfather was John Baker of Tenterden and his great-grandfather was Simon Baker of Faversham, Kent (Genealogist, 1890, 6: 242). He had a younger brother William and an elder brother Peter; the latter was an admiral of the Blue Squadron and died a prisoner of war in Spain. George must have been admitted to the Company of Barber-Surgeons some time in the $1560 \mathrm{~s}$, when he took up his career as a professional surgeon in London. By 1573, he was well on his way to success. On 10 May 1573, the College of Arms granted confirmation of his right to bear arms and crest (ibid). He was appointed personal physician to the young Earl of Oxford before 1574.

Baker had some difficulty in keeping his temper. Thus he fell out with his colleague William Clowes, whom he challenged to a duel. It is on record in the minutes of the Court of Assistants that on 25 March 1577 , there was at "this Corte ... .a greate contention and stryffe spoken of and ended betwene George Baker and William Clowes for that they bothe contrary to order and to the good and holesome rules of this howse misused eche other and fought in the ffelds together." The Masters, Wardens, and Assistants of the Company of Barber-Surgeons were obliged to intervene, and "wishing that" the two hotspurs "might be and continewe loving brothers", they "pardoned this greate offence in hope of amendment" (Sidney Young, The annals of the Barber-Surgeons of London, compiled from their records and other sources, London, 1890, p. 428). The two complied with the wish of the Company, making up for their gross misdemeanour by each editing a work of the other in 1579 .

Baker reaped the rewards of his professional virtues in the last decade of the century. Robert Balthorp, who had been Master of the Company in 1565 and 1573, died on 9 December 1591, bequeathing to Baker, "her maiesties Chirurgion", his "Syringe .. . and three pypes of silver gilted" (ibid., p. 530). On 4 February 1592, he was appointed to the office of the Queen's Sergeant-Surgeon, and on the following day was "liberate on the grant for payment of $£ 40$ a year" (typewritten biography). In August 1597, he was elected Master of the Company, while John Gerard (1545-1612) was chosen Junior Warden (ibid., p. 343). As Master of the Company, Baker wrote the address to the reader in Gerard's famous The herball or generall historie of plants (1597), praising the author for having "taken more paines than euer 


\section{G. Ungerer}

It was in the 1570s, as Charles Webster has pointed out, that the English surgeons under the impact of Paracelsian medicine began to dilute Galenic medicine by embracing chemical therapy. ${ }^{2}$ Baker was one of the first English surgeons to recommend chemical medicine in what happened to be his very first publication, The composition or making of the moste excellent and pretious oil called Oleum Magistrale. First published by the commaundement of the King of Spain, with the maner how to apply it particulerly. The which oyl cureth these disseases folowing. That is to say, wounds, contusions, hargubush shot, cankers, pain of the raines, apostumes, hemerhoids, olde vlcers, pain of the joints and gout, and indifferently all maner of disseases (London, Alde, 1574; STC 1209). ${ }^{3}$

Significantly, two of the leading members of the Barber-Surgeons' Company, John Banister and William Clowes, who were to propagate chemical medicine, voiced their support of their colleague in two Latin eulogies and a Latin encomium and English acrostic respectively; and circumspectly, in dedicating his publication to a member of the aristocracy, Edward de Vere, seventeenth Earl of Oxford, who had appointed him one of his personal surgeons, Baker shielded it from the censure of the medical authorities and traditional-minded physicians. Baker's enterprise must be seen as an attempt to reconcile chemical therapy with Galenic medicine, for the bulk of his first publication is devoted to Galen. It must be borne in mind that it contains Also the third book of Galen of curing of pricks and wounds of sinowes, as well as $A$ method for curing of wounds in the ioynts, and the maner how to place them and $A$ breefgathering togither of certain errours which the common chirurgians dayly vse. In fact, Baker's address to the reader leaves no doubt that at the outset of his career he took, like his colleagues Clowes and Banister, the stance of a staunch Galenist against empirics and "Paracellistes" who had done "great harme . . and dayly is committed" by them (sig. C2r).

\footnotetext{
Mathiolus did in his Commentaries." On 20 July 1607, Baker was appointed one of the Examiners of Surgeons, whose duty it was to present no candidate to the Bishop of London or the Dean of St Paul's with a view to obtaining a licence to practise surgery without a letter of admittance to the freedom of the Company testifying his ability to practise (typewritten biography). On 4 March 1610, he secured a grant, with survivorship, to himself and his eldest son Alexander, of the office of the King's Surgeon on surrender of a former patent (Calendar of State Papers Domestic, James I, 1603-1610, London, 1857, p. 591).

Baker also acquired considerable property. On 20 April 1597, he and his colleague William Goodrouse were granted a forty-year lease in reversion, without proviso for tenants, of Nunnington Mansion House and divers lands, tenements, and woods in Northfleet, Gravesend, and Milton (Calendar of State Papers Domestic, Elizabeth, 1595-1597, London, 1869, p. 391). Baker made his will on 25 August 1607. It was proved in London on 1 December 1612. Baker married twice. His first wife was Anne, daughter of William Swayne of Hacking, Middlesex. They had four children: Alexander, JP, Master of the Company in 1622, surgeon to James I, d. 1635 and buried in Westminster Abbey; Frances, Dowglas, and Ann. His second wife was Anne, daughter or possibly widow of Paul French, a prebend of Windsor. They had three children: George, Grace, and Elizabeth (typewritten biography).

${ }^{2}$ Charles Webster, 'Alchemical and Paracelsian medicine', in Charles Webster (editor), Health, medicine and mortality in the sixteenth century, Cambridge University Press, 1979, pp. 301-334.

${ }^{3}$ Copies of The composition are preserved at the British Library; Bodleian Library; Cambridge University Library; John Rylands University Library, Manchester; the Wellcome Institute for the History of Medicine, London; the Huntington Library, San Marino, California; National Library of Medicine, Bethesda, Maryland. I am obliged to these libraries for their replies to my queries. A facsimile reprint has been issued in the English Experience, no. 123, Amsterdam, 1969.
} 


\section{George Baker: translator of Aparicio de Zubia's pamphlet}

Baker's further publications bear witness to his support of chemical medicine. He next turned to the humanist Conrad Gesner, who was noted for advocating distillation chemistry in his handbook Thesaurus Euonymi Philiatri de remediis secretis...(1552). He knew that Peter Morwyng had translated the popular handbook under the title The treasure of Euonymus (London, 1559, 1565). There was even a second English version, which Thomas Hill had made from the augmented 1569 edition of Gesner's book. Baker took advantage of the work of his predecessors, issuing a revamped translation entitled The newe iewell of health, wherein is contayned the most excellent secretes of phisicke and philosophie...faithfully corrected and published in Englishe, by George Baker, chirurgian (London, Denham, 1576; STC 11798). In his address to the reader, signed from his "house in Bartholmewe lane beside the Royall exchaunge in London, this xxj. day of Februarye 1576", he recommended distilled medicaments as exceeding all others in virtue. He thought it advisable not to give a full description of the distillation, for he was against divulging the new knowledge to medical dabblers. He also left the names of the herbs in Latin, for he "would not have every ignorant asse to be made a chirurgeon". Again, he sought the patronage of the nobility, dedicating the book to Anne Cecil, the Countess of Oxford. ${ }^{4}$

Baker renewed his advocacy of chemical cures in the tract on The nature and property of quicksilver, which his colleague William Clowes edited in $A$ short and profitable treatise touching the cure of the disease called 'Morbus Gallicus' by vnctions (London, Day, 1579; STC 5447). ${ }^{5}$ Baker returned his colleague's favour by including the latter's Antidotary of select medicines, ${ }^{6}$ which showed the shift towards chemical therapy, in a compilation of traditional works taken from the medieval surgeon Guy de Chauliac and from Galen: Guydos questions. Newly corrected. Wherevnto is added the thirde and fourth booke of Galen, with a treatise for the helpe of all the outward parts of mans body (London, East, 1579;STC 12469). Also in the last translation to be published in his lifetime, Baker remained faithful to his policy of selecting authors who advocated the use of chemical therapy. Thus he revamped the translation which in 1543 B. Traheron had made from the medieval surgeon Giovanni de Vigo and brought it out under the title The whole worke of that famous chirurgion Maister Iohn Vigo: Newly corrected, by men skilfull in that arte. Whereunto are annexed certain works, compiled and published by Thomas Gale, Maister in Chirurgerie (London, East, 1586; STC 24723). ${ }^{7}$

In editing the works of Galen and Guy de Chauliac, Baker gave ample evidence that he did not envisage a break with traditional medicine. Yet his new orientation towards chemical medicine seems to have incurred the disapproval of the College of Physicians. Together with his colleague John Banister, he was denounced by the

\footnotetext{
1 In 1599, the book was reprinted by Peter Short under the new significant title The practise of the new and old phisicke. As the Countess had died on 6 June 1588, Baker dedicated the reprint to the Earl of Oxford. A facsimile reprint is available in the English Experience, no. 381, Amsterdam, 1971.

${ }^{5}$ This was probably a reissue of a lost 1576 edition (see Webster, op. cit., note 2 above, p. 327, n. 73). The Treatise was reprinted in 1585, 1596, and 1637. The STC does not record Baker's contribution to Clowes's publication.

${ }^{6}$ The entry in the $D N B$ ascribes the Antidotary to Baker; so does Henry J. Webb in his article on 'English military surgery during the age of Elizabeth', Bull. Hist. Med., 1944, 15: 261-275.

${ }^{7}$ Gale's Certaine workes in chirurgerie had been published in 1563.
} 


\section{G. Ungerer}

College as a surgeon guilty of illegal medical practice. ${ }^{8}$ Thus it would seem to follow that Baker's first publication on the "Oleum Magistrale" eventually contributed to the oil's English propagator being censured by the London College of Physicians, just as it had played, as we shall see, a decisive part in its inventor's being vilified and prosecuted by the body of professional physicians in Madrid.

Baker must have acquired a copy of the making of the "Oleum Magistrale" through either an English merchant or book agent. Unfortunately, no copy of the original Spanish government publication of Aparicio de Zubia's pamphlet is preserved.9 Its existence, however, is attested by a decree issued by the Spanish parliament on 15 April 1566. The parliament ruled that "se impriman dos mill tratados dello para que los procuradores de Cortes los lleuen a sus prouincias y los repartan; lo qual se cometió al licenciado San Pedro que lo haga hazer imprimir juntamente con Baltasar de Hinestrosa."10 Once printed, the pamphlet must have duly been distributed to all the provinces and must also have found its way across the Pyrenees and the Channel.

The pamphlet as it has come down to us in Baker's English version falls into three parts. First, the preface (sig. C4-D4v), written after the inventor's death and providing biographical information; second, 'The composition of the Oyle' (sig. E1r-v); and third, 'The maner to apply the saide Oyl' (sig. E1v-F2v). The last two parts came from the pen of Aparicio de Zubia, the first seems to have been written by a Frenchman. There is good reason to believe that Baker drew on a French translation, for there is evidence that he knew French, but there is none that he understood Spanish. Thus for the Third book of Galen, the companion piece of the Oleum Magistrale, he turned to the French epitome, which had been published as early as $1545,{ }^{11}$ and on his death he left behind an unpublished translation, The apologie and treatise, containing the voyages made into divers places, which he had rendered into English from the French text of the surgeon Ambroise Paré. ${ }^{12}$ In the

${ }^{8}$ Webster, op. cit., note 2 above, p. 328.

${ }^{9}$ The Centro Nacional del Tesoro Documental y Bibliográfico, Madrid, has not been able to locate a copy of the Spanish original. No copy is likely to turn up in a library, but there is some hope that one may be found in an archive.

${ }^{10}$ Actas de las Cortes de Castilla. Publicadas por acuerdo del Congreso de los Diputados ...Tomo II. Contiene las de Madrid, celebradas el año 1566, Madrid, 1862, p. 242. Rafael Muñoz Garrido drew on this document for his concise account of "El aceite de Aparicio" included in his article 'Empíricos sanitarios españoles de los siglos XVI y XVII', Cuadernos de la Historia de la Medicina Española, 1967, 6: 101-133. The surgeon Juan Fragoso confirmed in his Cirugia vniversal (Alcalá, 1592, colophon, 1591, fifth ed.; the original ed. is dated 1581) that the pamphlet had been written by Aparicio de Zubia himself. "Las virtudes de este azeyte", he wrote, "hallamos escriptas y firmadas del mismo Aparicio de cuuia en un memorial que hizo" (fol. 251r).

${ }^{11}$ Richard J. Durling, A catalogue of the sixteenth-century printed books in the National Library of Medicine, Bethesda, Maryland, 1967, p. 57. Durling observes that the abridgement has been ascribed to Jean Brèche of Tours. However, this translation is not listed among the works of Jean Brèche in the Dictionnaire de biographie française, ed. M. Prévost and Roman d'Amat, vol. 6, Paris, 1954. All the copies of the French translation kept at the Bibliothèque Nationale, Paris, are ascribed to Martin Grégoire: Tours, 1545; Paris, 1549; Lyons 1552 and 1574. All the editions bear different titles. The 1574 edition is entitled: De la composition des médicamens en général, rédigez en épitomé ou abrégé du grec en langage françois.

${ }^{12}$ The botanist Thomas Johnson published Baker's translation as Book 29, pp. 1133-1173, in The workes of the famous chirurgion Ambroise Parey (London, Cotes, 1634; STC 19189). In his address to the reader, Johnson states that "George Baker, a Surgeon of this City, since that time, as I heare, dead beyond the Seas", had translated the "Apologie, and Voyages" out of French. 


\section{George Baker: translator of Aparicio de Zubia's pamphlet}

preface to the Oleum Magistrale, the first name of the oil's inventor and the name of a former county in Spain are given in French. The text reads that "Aparice", the inventor, settled in Madrid, a town situated in "Castille la neufue" (sig. C4r-v). Baker's preface reads like an expanded version of a preface written to cater for a French public. ${ }^{13}$

The career of Aparicio de Zubia, his rise to fame, and the trials and tribulations he had to put up with can now be pieced together by means of the new information supplied by the preface to the Oleum Magistrale, which complements the data disclosed by the Actas de las Cortes de Castilla and the records discovered by Maria del Carmen Francés among the files at Simancas. ${ }^{14}$ The pattern of life that emerges from these records corresponds to the pattern of unorthodox Morisco practitioners in sixteenth-century Spain as studied by Luis García Ballester in Los Moriscos y la medicina. Un capítulo de la medicina y la ciencia marginadas en la España del siglo $X V I$ (Barcelona, Editorial Labor, 1984): a member of a repressed minority, an unauthorized Morisco healer endowed with an exceptional knowledge of herbs and their medicinal virtues, he was reduced to practising as an itinerant healer and to sharing the secret of his medicine with his wife in order to survive; he achieved spectacular cures in cases in which traditional medicine had failed, and consequently clashed with the medical authorities in urban cities; he managed to secure the support of the moneyed and ruling classes and even won royal acknowledgement.

The preface to the Oleum Magistrale, which we have ascribed to a French translator, confirms that Aparicio de Zubia was a Morisco healer, a new convert, who had apparently accommodated himself to Christianity and practised outside the narrow circle of university-trained surgeons. "In the Realme of Spain", he observed, "there inhabyted a people called in the Spanish tung Moriscus, of the which nation this Oyl was first practised, vnknowen to the Spaniards: which afterwards came to their knowledge and vnderstanding by the baptised Affricans, of the which nation there are a great number in Granado and Arogan." Raising the strident voice of international anti-Spanish propaganda, he went on to note that the Moriscos, "although they be not as yet growen so suttle and crafty as the said Spaniards: yet neuerthelesse it hath beene wel prooued and seen by experience that they haue had more knowledge then the said Spaniards, both in the secrets of nature, and also in the properties of herbs and generally in the art of curing" (sig. C4r).

As María del Carmen Francés has found out, Aparicio de Zubia was born in Lequeitio in the province of Vizcaya. By 1551, he had moved to Granada, the town with the greatest population of Moriscos, where he performed his first miraculous cure. The physicians of the Hospital of San Juan de Dios had given up all hope of curing a man suffering from a serious wound inflicted by a cutting weapon. When their conventional art of stopping the wound from bleeding had failed, that is, when they had given up the case as hopeless and commended the patient to God, Aparicio de Zubia was allowed to step in. He accomplished the cure in four days. His success

\footnotetext{
${ }^{13}$ The Bibliothèque Universitaire de Pharmacie, Paris, has not been able to trace a French copy. I wish to thank the librarian for her assistance.

${ }^{14}$ Maria del Carmen Francés, 'A Spanish secret remedy of the sixteenth century: "the Holy Oil of the Biscayan", in Wolfgang-Hagen Hein et al. (editors), Acta Congressus Internationalis Historiae Pharmaciae Bremae 1975, Stuttgart, 1978, pp. 49-57.
} 


\section{G. Ungerer}

"became so well known throughout Granada that thereafter ... he healed everybody and mainly poor people free of charge." As a result, divine qualities were attributed to his oil, which henceforth the Granadians called the "Holy Oil of the Biscayan". Its virtues gave rise to the proverb "Aparicio's oil is not holy, but it performs miracles."15

The people's support must have been a nuisance to the licensed surgeons. Time and again, Aparicio de Zubia had to face the hostility of the jealous professionals, who did not tire of suing him for unqualified practice. Even a royal licence granted by Charles V on 27 July 1552, which authorized him "to cure with the said oil the people who wished to cure with it any wound or illness"16 did not settle the dispute. Disillusioned as he must have been, he sought service in Flanders. It is not quite clear in what capacity he joined the Spanish army in Flanders. The Spanish infantry was organized in "tercios" of about twelve companies each, among whose staff officers there was a surgeon-major, a "chirurgeano mayor". ${ }^{17}$ Given the fact that Aparicio de Zubia was only an empiric, it is very unlikely that he was officially called upon to serve as a surgeon. He was probably a soldier in the army of Luis Carvajal and may have seen service in the battle of St Quentin, in which the Spaniards, on 10 August 1557 , triumphed over the French. He is known to have attended wounded soldiers in the Royal Hospital of St Quentin on what seems to be a charitable basis. He received no fee for his work, "not even food". ${ }^{18}$ It is tempting to speculate about the possibility that he may have met the English surgeon Thomas Gale (1507-87), who served under Philip II at the siege of St Quentin and whose Certaine workes of chirurgerie George Baker was to edit in 1586.

Aparicio de Zubia returned to Spain by 1559 , the year in which Philip II, hampered by lack of money, had to make peace with France. ${ }^{19}$ New difficulties arose on his return from Flanders. A letter, signed by Philip II from Valladolid on 26 January 1559 , cancelled the provisions set down by Charles V in 1552 . Despite this setback, Aparicio did not give in. He toyed with the idea of disclosing the secret of the oil's composition for the exchange of an annual pension. Thus, in 1559 , he went to Toledo to demonstrate the exceptional healing virtues of his oil. In the course of that year, he cured 107 patients in the Royal Hospitals of Toledo and Madrid, saving these institutions 500 ducats. ${ }^{20}$ After he had petitioned for a licence for twelve other persons to be allowed to use his oil on 20 September 1560 , the governors of the Royal Hospital of Toledo brought up the case in the national assembly during the session of 24 March 1561. They testified to the virtues of the oil-their evidence will be quoted below-and the members of the national parliament found the medicine "very beneficial and important", thinking "it would be convenient to register it and to make known its contents, so that when Aparicio de Zubia died this oil would not be lost." It is unlikely that the parliament approved the petition. Instead, it agreed to

${ }^{15}$ Ibid., pp. 49, 52.

${ }^{16}$ Ibid., p. 50.

${ }^{17}$ Geoffrey Parker, The army of Flanders and the Spanish Road 1567-1659, Cambridge University Press, 1972, p. 274.

${ }^{18}$ Francés, op. cit., note 14 above, p. 50.

${ }^{19}$ See John Lynch, Spain under the Habsburgs, Oxford University Press, 1965, vol. 1, p. 57.

${ }^{20}$ Francés, op. cit., note 14 above, pp. $50-51$. 


\section{George Baker: translator of Aparicio de Zubia's pamphlet}

grant him an annual pension of 30,000 maravedis, provided he disclosed the chemical formula of his balm. The amount offered was too little for Zubia to reveal his secret. ${ }^{21}$

The events that led to Aparicio de Zubia's death are recorded in the English preface. According to Baker, or rather his French source, it was about 1566 that Aparicio settled in Madrid where he came to be "esteemed of all men, aswel for the excellency of his art: as also for his great curtesy whiche he shewed vnto them" (sig. $\mathrm{C} 4 \mathrm{v})$. Yet the surgeons of the town took him to court. They denounced him as a quack who did "great injury \& wrong in medling with the art of the which he had no knowledge." As a result, the "Judges could doo no lesse then commit him to prison" (sig. D1r). The imprisonment caused an outcry of indignation among "certain gentlemen and others" who had experienced the beneficial qualities of his art and treatment. They "made with one consent a Supplication in his behalf for the bayling of him out of prison" (sig. D1v). The authorities assented to the petition and Aparicio was released on "condition that hee should medle no more with any cures, vntil suche time as he were authorised" (ibid.). He was a broken man when he was set free, for a long illness contracted in prison had drained away his strength. Importuned by the throng of people who sought his help, Aparicio violated the terms of his release and was again committed to prison. The ensuing protest against the authorities all over the town of "bothe Gentlemen, Burgesses \& merchants" was too strong for the king to ignore. As he was a "wise prince ... desiring the profit of his common welth", he took up the matter himself. He was curious to know the composition of the oil. But Aparicio refused to let the king in on the secret, even though he was offered a thousand ducats (sig. D2r). He died in 1566, without having revealed the composition of the Oil, as a result of "beeing very sore handled with his foresaid sicknes, and partly for the greef that he took of his wrongfull imprisonment" (sig. D2v).

Feeling that his death was imminent, Aparicio had confided the formula of the composition to his wife Isabel Pérez de Peromato, who had learned how to dress patients while her husband was in prison (sig. D3r). He had also made a deathbed disclosure to a Dominican friar. As the widow was forbidden to dispense the oil, she found herself in financial straits. She was therefore obliged to divulge the secret to the authorities, if we can rely upon the English preface, for five hundred ducats (sig. D3r-v). The official records yield more detailed information. On 4 April 1566, the widow petitioned the council for an annual pension of 50,000 maravedis, but had to content herself with an annual allowance of sixty ducats. ${ }^{22}$ On 2 May, payment was suspended on the suspicion that she had disclosed the wrong formula, ${ }^{23}$ yet thanks to the intervention of the Dominican friar, who confirmed the validity of the composition, the parliament lifted the suspension on 8 June $1566 .^{24}$

The formula of the "Oleum Magistrale" as it has come down to us in Baker's translation is more or less identical with the ingredients revealed to the physician

\footnotetext{
${ }^{21}$ Ibid., p. 51.

${ }^{22}$ Actas, op. cit., note 10 above, pp. 233-236.

${ }^{23}$ Ibid., p. 271.

${ }^{24}$ Ibid., pp. 339-340.
} 


\section{G. Ungerer}

Francisco Clero de San Pedro by Aparicio's widow. ${ }^{25}$ To be precise, "Sage" and "Sanguis draconis", the resin of the dragon tree, as given in the English translation, are not recorded in the list handed out to the Spanish authorities. On the other hand, Baker's version does not mention "Clean wheat". In the course of three centuries, Aparicio de Zubia's original formula went through several changes. "Myrrh" was not a component added in the seventeenth century, as María del Carmen Francés believes, but was already a part of the original formula. As there were doubts about the authenticity of the formula, many versions were put into circulation which had little to do with the original composition. To obviate any further abuse, Juan Fragoso, in his Cirugia vniversal, published the formula as it was disclosed, on 12 March 1567, by Aparicio's widow at the request of the parliament in the house of the physician Diego de la Gasca and in the presence of the physician Francisco Clero de San Pedro and Diego de Burgos, apothecary to the king..$^{26}$ The uncertainty about the true formula explains why John Banister, one of the encomiasts of Baker's 1574 publication, thought fit to issue a rectification in his An antidotarie chyrurgicall (London, 1589). It is headed "The true making of Oleum Aparitij, commonly called Oleum Magistrale, which hath been vntruly published heretofore by G.B." (p. 196). The formula as given by Banister was taken "Ex libro Hispanico", probably from Fragoso's. ${ }^{27}$ But Banister himself was as faulty as Baker, if one believes the report which claimed in 1595 that the true formula of Aparicio de Zubia's oil had been discovered in Segovia. ${ }^{28}$

What has remained unknown to the historians of Spanish medicine is Aparicio de Zubia's set of instructions on how to apply the oil, which are given in Baker's translation. The recipe for making the oil takes just over a page; the instructions how to administer it run up to eleven pages. This is not the place to assess Aparicio de Zubia's chemical composition. Suffice it to say that his success, as far as I can see, was due not so much to the oil's virtues as to the high standard of hygiene derived from practical experience. His success was attested by the governors of the Royal Hospital of Toledo who, on 24 March 1561, confirmed in the national assembly that Aparicio had cured "big wounds in heads and arms ... in five or six days' time ... in some cases it was not even necessary for the patient to avoid eating and drinking, and there was no fever ... it was not necessary for them to stay more than two or three days in bed, and in some cases no time at all; some needed no draining nor additional drugs; patients were not maimed as happened with people treated by surgeons; the art of Aparicio's treatment was cheaper than what surgeons charged." ${ }^{29}$

The effort made by George Baker in translating Aparicio de Zubia's pamphlet into English has to be seen as a contribution to chemical medicine in Renaissance England which, under the impact of Paracelsianism, was in statu nascendi. The originality of his contribution may be seen in the fact that he was the first English

\footnotetext{
${ }^{25}$ Baker, sig. E1r-v; Actas, op. cit., note 10 above, pp. $408-409$.

${ }^{26}$ See Alcalá ed. $1591 / 2$, fol. $250 \mathrm{v}-251 \mathrm{r}$; the first ed. was printed in 1581 .

${ }^{27}$ I owe this information to Christine R. English, Assistant Librarian, Wellcome Institute for the History of Medicine.

${ }^{28}$ See 1621 ed. of Juan Fragoso's Cirugia vniversal, pp. 471-472; see also Fragoso's comments on the properties of the oil, pp. 345-346.

${ }^{29}$ Francés, op. cit., note 14 above, pp. 50-51.
} 
George Baker: translator of Aparicio de Zubia's pamphlet

surgeon to turn to a Morisco empiric for the transmission of chemical therapy. This is all the more surprising if we bear in mind that in the reign of Queen Elizabeth, Spanish medical theory, unlike other arts such as navigation and warfare, was not made accessible in English at first hand.$^{30}$ The reputation of Spanish medicine rested solely on the Spanish physician and botanist Nicolás Monardes, the author of the Historia medicinal de las cosas que se traen de nuestras Indias occidentales (1565). The merchant John Frampton made Monardes accessible to English readers in a translation entitled Joyfull newes out of the newe founde worlde. The demand for this medical book, which treated "of the singular and rare vertues of certaine hearbes, trees, oyles, plantes, stones, and drugges of the West Indias", was so great that there were two editions in 1577 and two enlarged issues in $1580 .^{31}$

${ }^{30}$ See John Garrett Underhill, Spanish literature in the England of the Tudors, New York, Macmillan, 1899, pp. 30-31.

${ }^{31}$ Quoted from A.F. Allison, English translations from the Spanish and Portuguese to the year 1700, Folkestone, Dawsons, 1974, pp. 128-129. 